\author{
Aleksandra ZAJĄC \\ Uniwersytet Jagielloński \\ alexandrazajac@wp.pl
}

\title{
POLITYKA POETYCKA GIAMBATTISTY VICA
}

\section{ABSTRACT Poetical politics of Giambattista Vico}

The article presents a part of Vico's New Sience that is not so well known, but probably was a solid foundation of Vico's famous concept of ricorsi. The thinker's interest in poetical foundation of first societies is in a clear opposition with Cartesian and contractualist's visions of philosophy and politics dominant in his time. The article shows how Vico's connection to the renaissance tradition of poetical language gave him tools to explore the antiquity in a fruitfull way for philosophical and historical purposes. Nevertheless, it is partially also the tradition of Heidegger and Foucault, which makes Vico even more interesting to a contemporary reader. The article presents the poetical foundation of politics in concrete steps present in New Sience: the moment of foundation, religion of the first community, its language, morality, social structure, change, etc. It also explains epistemological means of human's becoming historical and political: ingegno, metaphor, myth, universals, dictionary of humanity, Eternal Ideal History. As to be complete, it deals with the issue so vividly discussed during medieval and renaissance times, that is of Homer, evidencing the pride of scientists. This all brings to the attention of a reader a totally original vision of the beginnings of zoon politicon that was and is in the first instance animal symbolicum.

Keywords: poetry, politics, language, antiquity, historiosophy

Słowa kluczowe: poezja, polityka, język, starożytność, historiozofia 
$\mathrm{T}$ ytuł niniejszego artykułu pochodzi z największej objętościowo części Nauki nowej Giambattisty Vica zatytułowanej $O$ mądrości poetyckiej. Jeden z podrozdziałów tej księgi to właśnie Polityka poetycka. Autor Nauki nowej, zanim wyrazi na końcu dzieła swoją koncepcję nawrotów historii, bez pośpiechu przedstawia świat starożytny. Rozległy, obfity w wyczerpujące przykłady i żmudnie kompilowany opis wyjaśniający, czym jest dlań starożytność, stanowi w Nauce nowej niemal autonomiczną jej część (270 stron). Vico poświęca mu szczególną uwagę z dwóch powodów. Po pierwsze, starożytność to czas pierwotny i pionierski, jeśli chodzi o tworzenie instytucji życia zbiorowego, które mogły powstać ze względu na poetyckie właściwości języka i mądrość tamtejszych społeczności (o czym dokładnie powiemy w tym artykule). Po drugie, dzieje się tak ze względu na nieskrywany sentyment Vica w tym zakresie. Pisząc krótko: Vico był zapatrzony w starożytność. Z wykształcenia prawnik, wykładał jednak na uniwersytecie w Neapolu retorykę. Rozmiłowanie w historii antycznej dzielił z pasją do języka i mądrości starożytnej - był zarówno filozofem, jak i filologiem. Czytając Naukę nową i badając raptowność, z jaką na ostatnich 60 stronach tego niespełna 600-stronicowego dzieła autor mówi coś o sławnych „nawrotach” (ricorsi) historii, nabiera się przekonania, że część wcześniejsza nie może zostać zmarginalizowana ze względu jedynie na spektakularność i nowatorstwo (tak ocenione przez późniejszych komentatorów) poglądów historiozoficznych. Przeciwnie, należy uwidocznić ją w całej pełni. „Polityczność" poetyckiego języka świata starożytności skłania do rozpatrzenia Vica na tle renesansu i humanizmu, inspiruje do zbadania powstałych wtedy koncepcji geniuszu, fantazji, pamięci jako naczelnych władz ludzkich w kontekście tworzenia pierwszych wspólnot politycznych, wiemy wszak, że Vico tę właśnie koncepcję poetyckiego początku przeciwstawiał wizjom kontraktualistów swoich czasów.

Plan tego artykułu obejmuje, po pierwsze, zbadanie wspomnianej renesansowej tradycji słowa poetyckiego, z której po części wypłynęła oryginalna koncepcja początku państwowości autorstwa Vica. Przy tej okazji wyjaśnimy, czemu Vico opierał się kartezjanizmowi dominującemu w jego czasach i według innej metody, właśnie tu prezentowanej, wolał wyjaśniać politykę. Mimo że być może res extensa i res cogitans pokrywa się z podziałem na świat naturalny i świat stworzony przez człowieka, jaki uznaje Vico, autor Nauki nowej i jego kluczowi komentatorzy podkreślają różnice pomiędzy nim i Kartezjuszem, dotyczące samych podstaw filozofowania. Podobieństwa między filozofami zostaną w artykule pominięte, zgodnie z wyraźnymi deklaracjami Vica, który całe życie otwarcie walczył z kartezjanizmem. Postaramy się wyjaśnić, czemu był mu tak przeciwny. Ponadto podział świata na naturę i kulturę istniał już w starożytności, więc niekoniecznie był skutkiem kartezjańskiej inspiracji. Po drugie, w artykule ukażemy pokrótce za Vico starożytny świat poetycki, łącznie z ważkimi rozważaniami dotyczącymi

Wyśpiewaj mi, o Muzo, cztowieka! Cytat z Horacego za: Vico e ilpensiero contemporaneo. Atti del Convegno Internazionale „Vico e il pensiero contemporaneo", Lecce, Novembre 9-11, 1989, red. A. Verri, Lecce 1991, s. 205. 
powstania wspólnoty, składowych jej języka i jego przekształceń, także religii, moralności budowanej na przykładach bohaterów, stosunków społecznych. Dookreślimy przy tym, niejako w oderwaniu od Polityki poetyckiej, ale na podstawie Nauki nowej i innych dzieł Vica, na czym polega u niego ingegnum, czym jest mit, metafora, powszechnik fantastyczny, czym z kolei uniwersalny racjonalny słownik ludzkości i Wieczna Historia Idealna, czyli jakie są „narzędzia” do osiągnięcia poetyckiego początku wspólnoty ludzkiej. Te kwestie epistemologiczne stanowią wieńczący wkład Vica w renesansowy nurt myślenia o języku. Postaramy się przedstawiać równolegle powstawanie wspólnoty ludzkiej i rozwój języka opisu tegoż „udziejowienia” człowieka.

Na początku przywołamy postać współczesnego filozofa, który pozwoli nam spojrzeć w sposób nieco bardziej życzliwy na, zdawać by się mogło, bajeczno-naiwną wizję Vica. Korzystając z propozycji Gaetana Cascavilli, do omówienia zagadnień pierwszej części artykułu wykorzystamy metodę Heideggera. Sam Heidegger interesował się humanizmem renesansowym, którego podsumowanie i zakończenie przypisuje się Vicowi (Przemyślat go [humanizm] aż do jego ostatecznych konsekwencji²). Wiemy także skądinąd, że miał świadomość myślenia „historycznego” obecnego w filozofii niemieckiej, zgadzając się z tezą Hegla, że naród niemiecki miał w swej naturze to szlachetne zadanie. Znał poezję: Trakla, Hölderlina. Był wyrazicielem zmierzchu metafizyki racjonalnej, teleologicznej i ontologicznej, czyli tradycyjnej i klasycznej. W swoim Byciu i czasie szukał odpowiedniej dialektyki dla ukazania istnienia, był też twórcą języka „filozofowania”, który niesie taką otwartość na przejawianie się istnienia. Jemu zawdzięcza się tłumaczenie starożytnego terminu nazywającego prawdę - alatheia - jako nieskrytość, ujawnienie, odsłonięcie. Za powyższym szło jednak odrzucenie konkretnych metod metafizyki tradycyjnej. Przede wszystkim było to cofnięcie zaufania do racjonalnego, logicznego, dedukcyjnego i abstrakcyjnego poszukiwaniu prawdy o strukturze świata na rzecz swoistej dialektyki, tymczasowych pewności, co by się pokrywało z vicowskim certo (pozostawanie na partykularnej, w danym kontekście uświadomionej pewności jako wytycznej działania w sytuacji niemożności skorzystania z wiedzy) i w ogóle odpowiadało renesansowemu rozumieniu języka „filozofowania”.

Jednakże teza Heideggera o końcu filozofii i początku prymatu dyskursu poetyckiego, podchwycona potem przez myślicieli francuskich, z Foucaultem na czele, nie była podobna do renesansowych koncepcji w całej ich rozciągłości. Dostrzegamy wyraźnie, że sprzeciwiała się temu nurtowi humanizmu renesansowego, który reprezentowała $\mathrm{XV}$-wieczna florencka szkoła Ficina, z jego thumaczeniem Platona oraz platonizmem metafizycznym i spekulatywnym tego okresu, tak silnie ześrodkowanym, że cały nurt nazwano neoplatonizmem. Istniał natomiast inny humanizm, ten wcześniejszy, który miał swoich epigonów w osobach Niziola, a poza Italią Vivesa i Graciana, wreszcie eksplodując w dziele Vica. Był to nurt, który proponował inne od klasycznego podejście do filozofii, zapoczątkowane teorią ingegnum, geniuszu. Nie co innego ma na myśli Heidegger, który miał stwierdzić, że nie stowo racjonalne może tutaj rościć sobie pretensję

Tamże, s. 193.

Tamże, s. 114. 
do prymatu, ale stowo poetyckie i metaforyczne, które posiada pierwotna sitę rozjaśniania ścieżki. Język jest domem istnienia ${ }^{4}$. Należy pytać o to, jak, na skutek jakiego mówienia i pisania o istnieniu ukazuje się ono, staje się „otwarte”. Tym krótkim odwołaniem do sposobu filozofowania Heideggera chcieliśmy pokazać, że nie mamy tu do czynienia z „bajaniem” literackim odległym od filozofii i politologii, ale że Vico jest przedstawicielem uzasadnionego i poważnego stanowiska w zapatrywaniu na język, co wpisuje go w jeszcze jeden ciekawy kontekst oprócz historiozoficznego, z którym jest często utożsamiany, pogłębia też nasze zrozumienie dla jego dokonań.

Pierwszym, który stawiał problem relacji między stowem poetyckim a realna struktura historyczna $a^{5}$, był Dante Alighieri w dziełach takich, jak De vulgari eloquentia i Convivio. Nota bene, jest to poeta uznawany przez Vica za Homera drugiego cyklu historycznego. Dante stawiał tezę, że poeta jest twórcą społeczności i on sam otwiera ją przez słowo poetyckie dla historyczności, w historię niejako wprowadza. Dante potępiał łacinę naukową, nazywając ją sztuczną i nazbyt „gramatyczną”, dlatego że nie odbijała historycznego rozwoju człowieka i języka. Łacina w tej wersji miała być z założenia niezmienna, jakże zatem mogła odwzorowywać i jednoczyć doświadczenie historyczne? Mówił o swoich badaniach językowych, że są poszukiwaniem pantery schowanej w gąszczu lasu różnych dialektów. Chciał stworzyć słowem nową przestrzeń, inną rzeczywistość polityczną, a tym samym otworzyć przyszłą epokę. Jego zdaniem polis jako miejsce przebywania wspólnoty nie było dane od początku, ale pojawiło się stopniowo dzięki słowu poetyckiemu, wyobrażeniom ujętym w pojęcia, które tworzyły świat i kulturę pierwotnej wspólnoty. W takim sensie, ze względu na tworzenie abstrakcji politycznych, czyli miejsca dla duchowego zamieszkania wspólnoty, można mówić o „polityczności” słowa czy też jego roli politykotwórczej. Język jest dla poety oratora w tym rozumieniu obowiązkiem, bo posiada moc, którą Heidegger nazwałby „otwarciem” - moc otwarcia rozpoczynającego życie wspólnoty politycznej, powołującego ład, pierwsze instytucje i linię rozwoju na przyszłość. Ten język jest teatrem, sceną, na której może pojawić się i wybrzmieć historia - przedstawienie. Doświadczenie stowa poetyckiego jest początkiem bistoryczności cztowieka 6 .

Nie tylko Dantego reprezentował omawiany nurt. Choć jego autorytet zwraca szczególną uwagę na głoszone przezeń tezy, w humanizmie renesansowym znajdą się i inne wielkie nazwiska. Proponujemy tutaj krótki ich przegląd, który pozwoli wyjaśnić, z jak nurtującą szkołą myślenia spotkał się Vico i z czego w zasadzie jego twórczość wyrastała. Silna była przede wszystkim tradycja rozważania verba i res, ale nie jako problemu logicznego odpowiedniości jednego względem drugiego, lecz jako sposobu uchwytywania przez słowo rzeczy, przekształcania jej dzięki słownemu określeniu i tworzenia świata ludzkiego przez nazywanie; ważne miejsce ogólnego namysłu stanowiła także tradycja filologii rozumianej dosłownie jako miłość do słowa, zajmowania się słowem. Leonardo Bruni, filolog i tłumacz tekstów klasycznych, odrzucał jakąkolwiek

Tami்e, s. 113-116.

Tamże, s. 119.

Tamże, s. 120. 
możliwość interpretacji języka poza jego historia i w oderwaniu od kontekstu spotecznego. Wszystkie słowa były dlań połączone na sposób mozaiki. Filologia - jego zdaniem - winna była zajmować się badaniem sytuacji zaistnienia słowa, ważne były dlań okoliczności, historia, która otaczała wyrażenie i je wydobywała. Nie ma to nic wspólnego z używaniem ratio, spekulacją na temat znaczeń słów, lecz wymaga innej ludzkiej zdolności - odnajdywania swoistego „przyporządkowania” słów do kontekstu, ich instancyjności ${ }^{7}$. Chodzi nie o co innego, jak o ingegnum. Tylko tak można połączyć słowa i wydobyć ukrytą za nimi rzeczywistość. Guarino Veronese, niezrównany renesansowy autorytet pedagogiczny, głosił przewagę litterae nad scientia rerum. Angelo Poliziano, burząc się przeciw sposobowi traktowania języka przez filozofię scholastyczną, deklarował, że odtąd nie będzie nazywał się filozofem, a gramatykiem. Lorenzo Valla również rezygnował z tytułu filozofa i nazywał siebie retorem. Humaniści, także Vico, byli zgodni co do twierdzenia, że poezja jest welonem, który ukrywa rzeczy. W jaki sposób kształtowałaby się zatem relacja między językiem poetyckim a rzeczywistością? Jeżeli poezja jest „okryciem”, welonem rzeczywistości, a jednocześnie, zdaniem humanistów, ma ją ukazywać, odsłaniać, czy nie napotyka się tutaj sprzeczności? Jest to tematem Genealogia deorum Boccaccia ${ }^{8}$.

Ten był zainteresowany ocaleniem mitologii starożytnej w obliczu ewidentnego braku potwierdzeń faktualnych. $Z$ wyznania katolik, zastanawiał się, jak możliwe jest zinterpretowanie bogów starożytnych unikające ich banalizowania. $Z$ tego względu stworzył teorię poezji jako skrywającej rzecz za welonem, ale także uchwytującej rzecz w jej sednie, niezaćmioną. Bajki starożytne były dla niego opisami przykładowymi, egzemplarycznymi i możliwymi do udowodnienia po uchyleniu zasłony. W retoryce przykład miał znaczenie podobne jak wynik indukcji, który nie był jednakże zasadą czy sednem, częścią wspólną indukowanych przykładów, ale uchwyceniem ich wszystkich za pomocą symbolu czy znaczenia9. Tym samym był możliwy do zmultiplikowania. Bajki zatem mogły osłaniać i odsłaniać cały świat. Poezja tak pojęta jest darem, ma siłę i charakter innowacyjny, jest początkiem historii człowieka, a wnioski te przejął Vico. Boccaccio podążał za swoim przeświadczeniem i udało mu się ustrzec od banalności greckich bogów. Niestety, zmuszony był i do pewnego ustąpienia, gdyż takie postawienie problemu historyczności, jakie przy okazji ufundował, kłóci się z doktryną chrześcijańską, która widzi historię jako motywowaną ku Rzeczy znajdującej się poza tą historią. Nie chcąc stracić tego, co już osiągnął, rzucił się w wynajdywanie metafor w Nowym Testamencie, próbował odnaleźć je w określeniach Chrystusa jako lwa, baranka, smoka; w Starym Testamencie Bóg jest krzakiem gorejącym. Tym samym nadał świętym pismom znaczenie fikcji (finzione) poetyckiej, a poezji „świętą” funkcję, bo zostaje oto awansowana do teologii nowego typu. Teza Boccaccia w konsekwencji jest taka: każdy partykularny

M. Marassi, Leonardo Bruni e la teoria della traduzione, „Studi Umanistici Piceni” 2009, Vol. 29, s. 128-129, [online] http://tuttoscorre.org/wp-content/uploads/2014/05/Leonardo_Bruni_e_la_ teoria_della_traduzione.pdf, 16 III 2016.

8 Vico e il pensiero contemporaneo..., s. 120-122.

9 E. Grassi, Vico and Humanism. Essays on Vico, Heidegger and Rhetoric, New York 1990, s. 65, Emory Vico Studies, 3. 
świat historyczny, ze swoimi bogami, instytucjami, świątyniami i aktami sakralnymi, stwarza się dzięki słowu poetyckiemu ${ }^{10}$.

Prace w tym zakresie kontynuował Coluccio Salutati, skupiając się na znanym w renesansie toposie prac Herkulesa jako metaforze zawładnięcia naturą przez człowieka. Doszedł do logicznych konkluzji w odróżnieniu od filozofów mu współczesnych, których błędem było potępianie języka poetyckiego przy jednoczesnej próbie symulowania go abstrakcją. Wybór stów, ich dźwięk, ich rytm prowadzi nas do rozpoznania pierwszej formy porzadku prawnego, który jest esencja mąrości $i^{11}$. Tym samym Salutati podkreślał, że poezja oddala od zmysłów, przy pomocy których człowiek na początku, w stanie pierwotnym, mógł rozpoznawać rzeczy, a tym samym tworzy pewną odległość między zmysłami, fizycznością a światem. Nakazuje ludziom wierzyć w coś przeciwnego temu, co widzą, tworząc przez to potrzebne wspólnocie abstrakcje polityczne. Czymś takim będzie u Vica pierwszy grzmot, który ludzie utożsamili z bogiem, nakazując sobie bogobojny strach i posłuszeństwo. Rzeczy z tego świata, jak ziemia, niebo, gwiazdy i słońce, zostały zhumanizowane. Słowo poetyckie stworzyło w ten sposób historię człowieka, ufundowało przestrzeń historyczną, w którą włącza się wszystko, co od tego czasu nastąpi.

Prawda, jaką mamy tutaj na myśli, nie jest prawdą logiczną, ale autorewelacją świata ludzkiego, dokonującą się przez ingegnum, z bogami, instytucjami i sferą duchową w oryginalnym, pierwszym znaczeniu. Vico przyczynia się do kontynuacji tego nurtu, ponieważ podobnie widzi początek świata ludzkiego czy „polityczny” stan pierwotny oraz nadaje wielkie znaczenie w swoim dziele ingegnum, fantazji, metaforze, pamięci (zostaną one przybliżone w dalszej części artykułu). Vico kontynuował wspomniany nurt na płaszczyźnie założeń metodologicznych i epistemologicznych Nauki nowej. Jego dzieło jest próbą ukazania pierwotnego odstonięcia, rozjaśnienia, w którym ukazuje się cztowiek [historyczny] $]^{12}$. Początek, od którego Vico wychodził, to samotność człowieka w sytuacji wyalienowania z natury, po której następuje tworzenie świata „ludzkiego". Nieoswojona natura budziła niepokój, była to sytuacja poprzedzająca zdominowanie świata przez człowieka. To, co obce i opresyjne, naturalne, zostało stopniowo ujarzmione przez poetyckie słowo, zapraszające do cywilizacji. Człowiek zakłócił spokój ziemi, podporządkowując ją swojemu byciu historycznym. Okazał się brutalnym agentem skazanym na działanie w ryzykownej sytuacji opadania w otchłań niehistoryczności i niepamiętającej natury. Z kolei historyczność mogłaby jego rozwój zacieśnić, gdyby nie publiczne „miejsca otwarte”, w których się realizuje jego wolność, samorządność, czynienie siebie poprzez praxis, bycie agentem dziejów. W tym wszystkim Vico przedstawiał człowieka jako posługującego się językiem poetyckim ${ }^{13}$.

W stworzeniu czy też, jakby to wolał nazwać Vico, odkryciu poetyckiej starożytności pomógł mu zapewne nawyk kreatywnego odczytywania źródeł. Nie zna „uległości” względem źródeł i naukowych autorytetów. Chce być ingegnoso - lotny, bystry,

\footnotetext{
10 Vico e il pensiero contemporaneo..., s. 124-125.

11 Tamże, s. 126.

12 Tamże, s. 128.

13 Tamże, s. 130.
} 
rzutki. Od autorów i dzieł bierze tylko to, co mu odpowiada, wersje okrojone czyichś całych koncepcji, często bez wzmianki o autorze. Warto przypomnieć w tym miejscu, że pierwsza wersja Nauki nowej była w formie czysto negatywnej, gdyż Vico przede wszystkim skupił się na wykazaniu, kto jego zdaniem nie ma racji. Czuł się zapewne często rozczarowany i nieusatysfakcjonowany lekturą. Powołując się na baconowskie idola, Vico kontestuje aberracje naukowe i psychologiczne jemu współczesnych względem odczytania starożytności, co usprawiedliwia wyłożenie przezeń później własnego poglądu na temat tekstów „pokrzywdzonych” niesłuszną interpretacją. Potrzebował alibi dlatego, że częściej i dogłębnie musiałby się tłumaczyć z mankamentów własnego wykładu starożytności, gdyby nie zapewnienie, że lepsza jest jego nieśmiała próba aniżeli trwanie przy najzupełniej niesłusznych teoriach dotychczasowych. Vico ponadto stosował - jak to rozumiał - „metodę Kopernika”, odwrócenia wszystkiego w poszukiwaniu korzystniejszego wyjaśnienia; używał także umyślnego przekręcania (misreading), by uzyskać użyteczne mu wnioski. Był nazywany czytelnikiem, który wypacza i nagina, czytelnikiem agresywnym ${ }^{14}$.

Chcąc zająć się już teraz wątkami politycznymi Polityki poetyckiej, powiemy na wstępie, że Vico naprawdę proponuje poetycką fundację wspólnoty ludzkiej. O szczegółach pisze wyczerpująco, aczkolwiek posługując się kategoriami mitu, poezji, metafory. Rozpoczyna opis powstania pierwszej wspólnoty politycznej historycznie znanej takim zdaniem: Ponieważ początki wszystkich rzeczy z natury swej sq niedorzeczne, winniśmy przeto uznać za początek madrości poetyckiej surowa metafizykę ${ }^{15}$. W świecie ludzi pierwotnych, nierozumnych i brutalnych miało miejsce ważne wydarzenie: grom z nieba przestraszył „gigantów”, szczególnie zaś „najdorodniejszych” z nich, a ten strach zrodził uniżenie przed pierwszym, wszechogarniającym i strasznym bóstwem - Jowiszem, utożsamianym poetycko z gniewnym i gromowładnym niebem. Tak oto poeci-teologowie zmyślili pierwsza boską baśń najwznioślejsza ze wszystkich, jakie kiedykolwiek później powstaty, baśn o Jowiszu gromowtadnym, królu i ojcu ludzi oraz bogów. Baśn ta upowszechnita się tak dalece i takie wywotata wrażenie, że sami jej twórcy uwierzyli w nią i ta sama wiara [...] wzbudzita w nich $w$ stosunku do Jowisza cześś, lęk i postuch ${ }^{16}$. Rozpoczęło to drogę mądrości, której wyraz mógł być ze względu na brak refleksyjności i racjonalnego myślenia tylko poetycki: u pogan muza oznacza początki madrości $i^{17}$. Z tej mądrości wyrósł jeden z trzech rodzajów teologii, które towarzyszą rozwojowi ludzkości, teologia poetycka (obok naturalnej i objawionej). Wymóg interpretacji woli boga stworzył ponadto wróżbiarstwo, czyli naukę o mowie bogów. Muza poetycka czy mądrość poetów-teologów oznaczała także znajomość boskich auspicjów. Wiedza ta u wszystkich narodów byta pospolita umiejętnościa kontemplowania Boga jako opatrzności $1^{18}$. Zaciekawia

14 A. Battistini, Vico lettore agonistico, „Studi di Estetica” 1991, R. 19, ser. 3, nr 3/4, s. 252-257.

15 G. Vico, Nauka nowa, przeł. J. Jakubowicz, oprac. S. Krzemień-Ojak, Warszawa 1966, s. 159, Biblioteka Klasyków Filozofii.

16 Tamże, s. 170.

17 Tamże, s. 156.

18 Tamże, s. 158. 
to o tyle, że Vico w Nauce nowej wprowadził opatrzność jako siłę kierującą historią. Wygląda na to, że jego zdaniem w sposób prymitywny była ona postrzegana już od pierwszego etapu dziejów. Mądrość poetycka wykorzystywana była następnie w sądownictwie, przy orzekaniu wyroków i kar; znane było starożytności szerokie jej uwzględnianie w sprawach instytucjonalnych, porządkowych, państwowych. Powstał też zwyczajny kult, bałwochwalstwo, składano ofiary.

Vico jest w stanie wyznaczyć przebieg późniejszych dziejów tej wspólnoty: Wykażemy jasno i wyraźnie, jak twórcy cywilizacji pogańskiej wyobrazali sobie bogów w swej teologii naturalnej, czyli w metafizyce, jak logika umożliwita im wynalezienie języków, moralnośćs stworzenie bohaterów, ekonomia zatożenie rodzin, a polityka zbudowanie miast ${ }^{19}$. Zatem jego wizja początku daje dość kompleksowy ogląd świata społecznego. Dla zrozumienia kolejnych etapów rozwoju ludzkości, które później, przy przedstawianiu teorii nawrotów historii, okaże się niezbędne, potrzebna jest konstatacja, że to wewnętrzne modyfikacje samego umystu [są] źródtem wiedzy o zasadach życia ludzkiego. Odwzorowanie predyspozycji umysłowych, którymi ludzie dysponują w danym czasie, decyduje o rodzaju instytucji, z którymi w tym czasie mamy do czynienia. Umysłowość człowieka wpływa też na charakter metafizyki, języka, sposoby pojmowania świata: Dlatego to mądrość poetycka, owa pierwsza mądrość pogańska, musiata się rozpoczać od metafizyki, jednak nie rozumowanej i abstrakcyjnej jak dzisiejsza metafizyka erudytów, ale od metafizyki opartej na uczuciu i wyobraźni $i^{20}$.

Na styku życia zupełnie nieświadomego, a zatem jedynie naturalnego, oraz tego kulturowego czy historycznego przybrała formy poetyckie w języku czy teologii pierwsza percepcja świata, która miała wzbudzić polityczne działanie. Zdolność ta rodzita się z nieznajomości przyczyn: wszystkie zjawiska, których przyczyn nie znali, budzity wnich zdziwienie i gtęboki podziw [...]. Równocześnie przypisywali oni rzeczom podziwianym byt subtelniejszy, zgodnie ze swymi ideami, co jest tak charakterystyczne dla natury dzieci ${ }^{21}$. Celami tej poezji było tworzenie wzniosłych baśni, dostępnych pospolitemu rozumieniu, wstrząsanie do głębi, ażeby doprowadzić do wyznaczonego celu: nauczyć pospólstwo, by postępowało cnotliwie. Zauważalne od początku nakierowanie na cnotę jest, zdaniem Vica, kolejny raz potwierdzeniem, że w tej pierwszej metafizyce ogarniano już zamysł opatrzności. Droga rozwoju przebiegała podobnie w całym świecie starożytnym, chociaż Vico zawsze będzie traktował jako wzorcową starożytność grecką i rzymską. Zadziwiająco wielu jest Jowiszów, każdy bowiem naród pogański miat swojego Jowisza, a Egipcjanie [...] twierdzili w swej pysze, że ich Jowisz Ammon jest z nich wszystkich najstarszy. Równie wiele jest też przekazanych w baśniach opisów fizycznych, świadczacych o powszechności potopu ${ }^{22}$.

Zanim postąpimy w przedstawianiu poetyckiej fundacji polityki, zróbmy w tym miejscu krok w tył, żeby w jeszcze inny sposób umotywować zastosowanie "poetyczności”, którego pierwsze przybliżenie może zrazić „nienaukowością” (chociaż przecież

\footnotetext{
19 Tamże, s. 160.

20 Tamże, s. 167.

21 Tamże.

22 Tamże, s. 171.
} 
i Lewiatan Hobbesa jest li tylko nienaukową hipotezą). Giambattista Vico był przeciwny bardzo wpływowemu w jego czasach kartezjanizmowi. Podczas gdy w czasach Platona matematyka miała - jeśli w ogóle - to tylko propedeutyczne zastosowanie, to w XVI wieku kartezjańskie zaufanie do geometrii analitycznej zaczęło dominować w akademickim świecie. Kartezjanizm w czasach Vica stał się prawdziwym fundamentem filozofii naturalnej. Za radą Kartezjusza próbowano ograniczyć przedmioty warte filozofowania do tych przejawiających naturę stałą na tyle, by dać wiedzę pewną, niepowątpiewalną. Ku zgorszeniu Vica znaczyło to odcięcie całego świata społecznego od refleksji filozoficznej, gdyż taki charakter (niepewność i powątpiewalność) od starożytności nadawano sprawom społecznym. Kartezjanizm spolaryzował prawdę i fałsz, pomiędzy nimi nie pozostało nic. Nie była możliwa dysputa na temat kwestii niepewnych, której rezultatem miało być dojście do prawdy (prawda była osiągalna tylko w nauce). Retorykę Kartezjusz jawnie potępiał: Ci, którzy maja rozumowanie mocniejsze i lepiej wiedza, jak ksztattować swoja wypowiedź, by byta jasna, sa zawsze najbardziej przekonujacy, nawet jeśli mówią tylko stabo po bretońsku i nigdy nie studiowali retoryki23.

Już nie dyskusja w ramach wspólnoty, ale kalkulowana, skąpa myśl staje się kluczem do postępu społecznego. Jeszcze bardziej stało się to oczywiste dla współczesnych Vicowi dzięki rozprzestrzenieniu myśli Kartezjusza przez Arnaulda. To jego przeciwstawiał Vico Cyceronowi, który uosabiał dla niego epokę, w której być wykształconym, oznaczało opanować elokwencję, w której zdolności retoryczne ujawniają umysł wykształcony w pełnym cyklu zdobywania wiedzy. Vico zdawał sobie sprawę z tego, że nowe praktyki nie zaszczepiłyby się tak szybko, gdyby stare nie uległy pewnemu rozbiciu. Łatwo można to było zauważyć, wszak sam Platon zetkną się już z niepochwalanym przez niego oddzieleniem filozofii od retoryki, które pozwoliło narodzić się demagogii i podzieliło społeczeństwa na fakcje. W De oratore Cyceron pisał o rozdziale między językiem (to jest wyrażaniem) i sercem, który widział jako absurdalny, niepotrzebny i godny potępienia. A karygodnym już zupełnie tego rezultatem był dlań fakt, że moralności nauczali inni nauczyciele aniżeli ci, którzy zajmowali się nauką retoryki ${ }^{24}$.

Vico bierze udział w wojnie klasyków z „nowożytnikami”, sławnej querelle des anciens et des modernes, broniąc przede wszystkim kategorii sensus communis, zdrowego rozsądku. Twierdził, że ludzie, działając publicznie, przejawiają „porządkującą” linię postępowania. Sensus communis należy uznać za ważny i nieredukowalny czynnik życia społecznego. Tak pisał Vico jeszcze w De antiquissima, sądząc, że stosowanie pewników z metod geometrycznych do spraw społecznych przeczyłoby naturze spraw ludzkich, od zarania dziejów jednako kapryśnej, nieprzewidywalnej, podległej okazjom i losowi (tu pojawiają się kategorie Machiavellego). Poza tym „geometria” społeczeństwa zmieniłaby tradycję uczenia młodych retoryki, kreatywności, fantazji, zanegowałaby stary tryb edukacji, w którym tylko praktyka i „wrośnięcie” w tkankę społeczną, przesiąkniecie sprawami ludzkimi dawały przyszłych ekspertów ${ }^{25}$. Takie poglądy wynikały raczej

\footnotetext{
23 M. Mooney, Vico e la tradizione della retorica, Bologna 1991, s. 30, Saggi, 394.

24 Tamże, s. 32-33.

25 Tamże, s. 26.
} 
z jakiegoś osobistego etosu i postawy, zarówno życiowej, jak i prezentowanej na uniwersytecie, która czerpała z klasyków starożytności. Już Arystoteles pisał, że w „rzeczach ludzkich" daremnie szukać episteme, jedyne, co da się wypracować w odpowiednich obszarach, to techne, skuteczne działanie. Natomiast jak płaszczem nieogarniony chaos rzeczy zmiennych, społecznych winna zakrywać prudenzia, roztropność. Vico mówi z perspektywy pedagogiki i kultury, wypowiada się jako profesor retoryki.

To wszystko, zdaniem Mooneya, było pierwszym powodem rozpoczęcia żmudnej pracy nad Nauka nowa. Przecież miało to być, jak zamierzał Vico, najbardziej nowoczesne dzieło z zakresu krytykowanej dotąd historiografii. Gdzie indziej zatem musiało leżeć jej nowatorstwo, bo podczas gdy Kartezjusz mógł rządzić wszędzie, w Neapolu aktualny był w tym czasie nadal Cyceron. Antykartezjanizm Vico przejawiał się w tym, że wciąż jeszcze widział miejsce dla studiowania, w którym ujawnia się geniusz, przemyślność, bystrość. Nawet na studiowanie z odpowiednim nastawieniem geometrii znalazłoby się tu miejsce. Dzięki niej uczeń rozwijałby zmysł topologii, a dzięki temu z kolei nadawałby się coraz bardziej do „prześwietlania” rzeczy prawdopodobnych. Nie wszystko mogła zastąpić fizyka i mechanika. Cywilizowanie oznaczało dlań uczenie obchodzenia się z tym, co niepewne, rozbudzanie wszelakiej pomysłowości, która miała takim niedostatkom zaradzić. W Nauce nowej szacunek dla retoryki przejawiał się w powierzeniu tak licznych zadań filologii oraz przywiązywaniu wielkiej wagi do systematyzacji.

W innym jeszcze miejscu przejawiła się niezgoda na nową metodę proponowaną przez Kartezjusza. Przede wszystkim jako pedagog pracujący na co dzień ze studentami Vico zdeprecjonował krytykę autorstwa Kartezjusza jako metodę, która dochodzi do prawdy poprzez negację tego, co jedynie prawdopodobne, wątpliwe, niepewne. Jako sposób prowadzenia zajęć krytyka zawodzi - jej metoda jest nie do zaproponowania jako punkt podparcia planu zajęć [uniwersyteckich - przyp. A.Z.], a jej prawda „nieodpowiednia" jako koniec, wynik nauczania ${ }^{26}$. Niepewność nie jest czymś, co trzeba wyjaśnić, rozjaśnić, zredukować za pomocą cierpliwego i upartego analizowania, jest to kontekst i prawdziwy charakter życia, przynajmniej jeśli chodzi o świat społeczny. Jedyna obrona to umysł czynny i szybki, a nie metodyczny i dedukcyjny. Nic, co dedukcyjne, nie stworzy czegoś praktycznego. Prawdopodobieństwa uzyskują gotowość do bycia pewnikami jedynie poprzez dyskurs. Nauka zmierza do prawd najwyższych, rozwaga spoteczna do prawd najniższych ${ }^{27}$.

W tym kontekście Vico w poważnym dziele, jakim jest Nauka nowa, traktującym przecież także o kwestiach epistemologicznych i wprowadzającym koncepcję historiozoficzną, do której będą się odnosić filozofowie kanoniczni, tacy jak chociażby Hegel czy, z bardziej współczesnych, Berlin, proponuje hipotezę powstania państwowości zadziwiająco oryginalną. Chociaż surowy dryl racjonalistyczny filozofii współczesnej stroni od koncepcji podobnych „polityce poetyckiej”, przybliżamy ją jako fragment dzieła uznanego filozofa. Owo znużenie współczesnego czytelnika, wykształconego

\footnotetext{
26 Tamże, s. 165.

27 Tamże, s. 171.
} 
na uniwersytetach promujących naukowe, a nie humanistyczne podejście do filozofii, jednakowoż skupiających się na filozofii systematycznej (ontologii, epistemologii) bardziej niźli na moralnej, bierze się stąd, że filozofię moralną chętnie uznawano potocznie za ostatni bastion wsteczności, „metafizyczną”, nienadążającą za dokonaniami bardziej „naukowej” filozofii systematycznej. Przystąpienie do czytania Vica, jakkolwiek „poetycka" miałaby to być koncepcja, musi się mimo to oprzeć na podstawowych zasadach przystępowania do nowej propozycji filozoficznej w ogóle, to jest na poznaniu problemów badawczych, zapoznaniu z metodologią i narzędziami poznawczymi; dopiero w tak wytyczonym polu rozpatrujemy propozycję, patrzymy na jej wewnętrzną spójność. Miejmy nadzieję, że obecne przedstawienie narzędzi poznawczych Vico pomoże, jak wcześniejsze uprawomocnienie renesansowego nurtu myślenia o języku poprzez odwołanie do współczesnego geniuszu Heideggera, spojrzeć życzliwiej na „poetycką” koncepcję powstania świat politycznego.

Przyjrzenie się bliżej, jak owo objawienie Jowisza odcisnęło piętno na umysłach ludzi, wymaga powiedzenia czegoś więcej o poetyckości pierwszego języka. Na czym ona polegała? Przede wszystkim język ten powstał w drodze naturalnej, jako wynik czynników psychicznych wewnątrz samego człowieka, bardzo dosłownie mówiąc - ze strachu. Strach ten „budził” świat i przedmioty, a język był nań reakcją, polegającą wpierw na - poetyckim - nazwaniu jego przyczyny i przyjęciu odpowiedniej względem niej postawy. Jowisz miat więc rządzić za pomoca znaków, które byty przedmiotowymi stowami (parole reali), a natura miata być jego jezykiem ${ }^{28}$. Postawa strachu była szczerym uznaniem słabości i niemożności człowieka. Widzimy tutaj zaczątek wyczucia hierarchii. Człowiek plasował się niżej od boga - natury. Paradoksalnie, świadomość, która przegrywa poniekąd z nieświadomym żywiołem kosmosu, wygrywa z nim w swych wytworach - wspólnocie politycznej, kulturze, „zagłuszając” naturalność historycznością. Pierwszy język, język bogów byt niemal catkowicie niemy, ledwie że artykutowany ${ }^{29}$. Był to ten język krzyku i strachu przed gromem - Jowiszem, język zdziwienia. Ponieważ jednak bardziej interesuje Vica świat historyczny i polityczny, często przechodzi on szybko od pierwszego do drugiego historycznego języka, nazywając wspólnie języki boski i bohaterski - poetyckimi. Z podobieństw rozwoju różnych ludów oddalonych od siebie geograficznie wnosi, że bezsprzecznie wszystkie ludy pierwotne byty poetami ${ }^{30}$. Co znaczą przedmioty słowne, o których wspomnieliśmy? Otóż człowiek nieinteligentny specyficznie używa nazw znanych mu rzeczy, np. stosuje określenie: „głowa”, mając na uwadze początek: język bohaterski obfitowat w analogie, obrazy, porównania. Przyczyna tego byt brak określeń wtaściwych rodzajom i gatunkom, niezbędnych przy definiowaniu rzeczy za pomoca ich cech. Jezyk ten powstat zatem w wyniku naturalnej konieczności, wspólnej wszystkim narodom ${ }^{31}$. Powstanie języka budującego życie społeczne człowieka charakteryzowała, po pierwsze, inwencyjność (fantazja, vicowskie ingegno), po drugie,

\footnotetext{
G. Vico, Nauka nowa, s. 171.

Tamże, s. 217.

Tamże, s. 230.

Tamże, s. 449.
} 
bogactwo środków stylistycznych (najwięcej miejsca Vico poświęca metaforze) oraz odpowiedniej formy przekazu, czyli mitu, oraz po trzecie, powstanie powszechników. Dokonania tych mitycznych czasów zostały utrwalone w historii ludzkości aż po teraźniejszość. Uznawano poetów narodów pogańskich za mędrców: nadali oni bowiem rzeczom nazwy zgodne z ich natura i wtasnościami. Stąd też, jak widzielismy, u Greków $i$ Latynów stowa nomen $i$ natura znaczyty jedno i to samo ${ }^{32}$. Dlatego też, po czwarte, zrozumienie fundacji dziejów w starożytności zainspirowało Vica do próby stworzenia słownika uniwersalnego ludzkości oraz zapoczątkowało wyznaczanie faz w Wiecznej Historii Idealnej (metodzie ujęcia dziejów w Nauce nowej).

Po pierwsze zatem, sukces Vica w stworzeniu takiej spójnej wizji początków historyczności człowieka jest tym większy, że filary jego konstrukcji są ulubionymi przez niego: fantazją i ingegnum. Na wstępie należy jeszcze, z czysto technicznego punktu widzenia, rozróżnić fantazję, ingegnum i - pomocniczą im - pamięć. Fantazja albo wyobraźnia jest tą władzą przysługującą wyłącznie człowiekowi, która pozwala zastanawiać się nad bodźcami, których nie ma w bezpośrednim obecnym postrzeganiu. Ingegnum jest władzą pozwalającą organizować znaczeniotwórcze jednostki wyobraźni czy fantazji w jednostki i struktury na wyższym poziomie konkretności. Tak więc ingegnum bezpośrednio odpowiada za wynalezienie mitów i w ogóle dyskursu. Pamięć zaś pozwala gromadzić to, co uchwytywane przez fantazję, by geniusz mógł zmierzyć się z tym później albo by dane nie ulotniły się tylko dlatego, że nie zostały natychmiastowo spożytkowane $e^{33}$.

Metafizyka Vica została od początku nazwana antyracjonalistyczną. Na płaszczyźnie politycznej wyraźnie odrzuca chęć widzenia we wszelkich powstałych instytucjach i społecznych dokonaniach człowieka dedukowanych zasad jako początków. To także nazywa próżnością ${ }^{34}$. Nie ma rozumu „za” mitami, bajkami, opowiadaniami o początkach. Akademie i filozofów umieszcza rozmyślnie na samym końcu w porządku zdobywania przez człowieka wiedzy ${ }^{35}$. Zakłada to między innymi niezbędność geniuszu (ingegnum), niejako intuicyjnego odnajdywania, by później rozumowo osądzać. Potrzeby i przynaglenia, którym musiał sprostać człowiek prymitywny, były zadane przez opatrzność, aby zaradzając im, zbudował wokół siebie świat społeczny ${ }^{36}$. Ingegnum ludzi pierwotnych należy uznać za odpowiedź bogu, gdyż wszystkie potrzeby uważali oni za boskie. Wynikiem ludzkiego niedostatku jest mądrość poetycka, która przerosła w swych rezultatach późniejszy rozum ${ }^{37}$. Wynika z tego, że człowiek jest najbardziej językowo i poznawczo rozwinięty w pierwszym stadium rozwoju języka. Ubóstwu języka towarzyszyła bowiem płodność wyobraźni, dzięki której powstali bogowie,

\section{Tamże, s. 241.}

33 M. Danesi, Vico, Metaphor, and the Origin of Language, Bloomington 1993, s. 50-51, Advances in Semiotics.

34 Vico e il pensiero contemporaneo..., s. 195.

35 G. Vico, Nauka nowa, s. 363.

36 Vico e il pensiero contemporaneo..., s. 197.

37 G. Bedani, Vico Revisited. Ortodoxy, Naturalism and Science in the Scienza Nuova, Oxford 1989, s. 63. 
by usankcjonować rozwój społeczny ${ }^{38}$. Geniusz rozwinął się przed refleksją i jemu należy zawdzięczać wprowadzenie człowieka do świata historycznego.

Jeśliby chcieć, po drugie, powiedzieć teraz coś więcej o metaforze czy też środkach stylistycznych w ogóle i o micie, to Vico przede wszystkim proponuje skrzyżowanie metafory i świadectwa jako kryterium hermeneutyczne ${ }^{39}$. Te dwie kategorie zazębiają się w homo symbolicus, wskazując, że należy odczytywać człowieka jako skazanego na kondycję hermeneutyczną. Nie zjawia się on w świecie doskonale i całkowicie zintegrowany ani też nie świętuje choćby dopiero z biegiem czasu autorealizacji, ale pozostaje ciagle w sytuacji perspektywicznej, kierując się na thelos. Prawda jezyka nie polega na reprezentacji świata poprzez znaki, ale raczej na jego interpretacji jako sytuacji konstytuujacej cztowieka i dlatego znaczacej dla jego egzystencji $i^{40}$. Dla Vica metafora jest rozświetlająca; jest zaimprowizowanym zrozumieniem, niezbędnym przy niemożności innej komunikacji. Występuje często, nawet nierozbudowana od razu posiada gęstą sieć skojarzeń i możliwości znaczeniowych, do których może prowadzić.

Nawiązując na moment do Kanta, zauważa się od razu, jak daleko od głównego prądu swoich czasów, kartezjanizmu, probierza nowoczesnej filozofii, oddalony jest Vico. Kant uważał, że wrażenia zmysłowe niezsyntetyzowane przez formy transcendentalne są czystą nieuformowaną obecnością, nieczytelną dla człowieka, inaczej niż widział to autor Nauki nowej. Metafora dla Vica miałaby może coś z Ricoeura la métaphore vive, której pierwszorzędne zadanie nie zawiera się w ubogaceniu dyskursu, lecz w przekazaniu kodów nieprzekazywalnych inaczej ${ }^{41}$. Vico był zdania, że poznanie poetycko-metaforyczne jest całkowicie samowystarczalne, to znaczy umie jakościowo i ilościowo zastąpić nieistniejące w czasie jego występowania poznanie rozumowe.

Język poetycki zrodzita konieczność wypowiadania się, a charakteryzowato ubóstwo środków, o czym świadcza pierwsze ozdoby języka poetyckiego, jakimi sa: hiperbole, naśladowania, porównania, peryfrazy, zwroty określające rzeczy przez odwotanie się do ich cech przyrodzonych, opisy olsniewajace zmysty bogactwem szczegótów, a wreszcie dygresje emfatyczne, niejednokrotnie zbędne ${ }^{42}$. Z czasem, w miare jak stabta wyobraźnia, a wzmacniata się abstrakcja, personifikacje te zmniejszyty się do rzędu niewielkich znaków. Metonimia ukryta wówczas, pod pozorami uczoności, nieznajomośc ciemnych aż dotąd początków spraw ludzkich. Znakiem rozpoznawczym języka czasów poetyckich jest metafora użycza rzeczom nieożywionym uczuć i namiętności, tak, że każda metaforę można uwa$\dot{z} a c ́$ za krótka bajkę. Metonimia i synekdocha odpowiadały zaś za nazywanie rzeczy od idei konkretnych i zmysłowych ${ }^{43}$.

Mity zalecały praktyki, które, jak wyrozumiano, okazywały się najlepsze w danych okolicznościach dla człowieka. Były zapisem rozumienia świata w sensie przyczyn

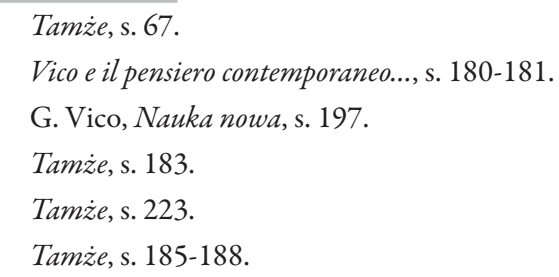


i konsekwencji ludzkich działań. Mit determinował poszczególne działanie poprzez nakreślenie generalnego przykładu, nie abstraktu, ale tak zwanego uniwersalium fantastycznego, ideału ${ }^{44}$. Zgodnie z tym rodzajem systematyzowano poszczególność, czyli dedukowano o sposobie postępowania w konkretnej sytuacji ${ }^{45}$. Moralność starożytna nie miałaby zatem zasad przewodnich, ale przykłady do naśladowania. W mitach występowały osobowości-przykłady, chociażby Herkules, Romulus, Solon, Penelopa.

Co do formy, mit był narracyjnym opisem zewnętrznego świata. Był prawdziwy dla twórcy w takim samym sensie, w jakim współczesne teorie naukowe są prawdziwe dla badaczy ${ }^{46}$. Pokazywał zapamiętany stan i strukturę umysłu ludzkiego pod wpływem naturalnych konieczności ${ }^{47}$. Stanowił literalnie prawdziwy wyraz tego, jak postrzegano rzeczywistość. Nie mogło być mowy o zwodzeniu, dlatego że ta umiejętność, jako właściwa refleksji w formie zwulgaryzowanej i wykolejonej (jak sądził Vico), nie była człowiekowi pierwotnemu jeszcze dostępna. Mit miał mieć zatem bardzo naturalne, życiowe pochodzenie, ale też takie zastosowanie, a pierwszy człowiek był jako poeta zarazem historykiem swojego czasu i sprawozdawcą, łączył w sobie cechy uczestnika wydarzeń i naukowca rozważającego to, co się zdarzyło.

Sens, jaki przypisuje Vico mitowi w Nauce nowej, rozszerza się poza bycie prawdziwą opowieścią (o walorach moralnych) członka zamierzchłej społeczności i odsłania sam sposób pojmowania i zdobywania wiedzy przez człowieka początków. Mit to nie tylko to, co się mówi, ale samo to mówienie, sposób, w jaki to, co się mówi, jest powiedziane i poprzez wypowiedzenie jest po raz pierwszy zrobione i odkryte. Język mityczny jest językiem składnym, dosłownym, ale znajdują się tu zasady semantyczne, które stoją u źródeł humanizacji natury. To, czym przewyższa mit refleksję, to racjonalnie niededukowalne formy inwencyjne, wyniki zrozumienia, które zawsze poprzedza dedukcja, ponieważ można wyciągać konsekwencje tylko wtedy, kiedy już się zrozumiało. Mity były odpowiedzią na szukanie przez samego człowieka „miejsca”, w którym miałaby rozwinąć się jego historyczność: Stowo poetyckie jest jedyna oryginalnie ludzka próba nadania sensu strasznej mocy istnienia, które się ukazuje w istniejacym. Tylko próba pokonania tej mocy może pozwolić ukazać się światu historii. Takie poznanie od zera zdarzyło się tylko raz w dziejach i to właśnie $\operatorname{tam}^{48}$.

W konsekwencji, przechodząc do punktu trzeciego, zaistniały w języku i w umysłowości człowieka pierwotnego uniwersalia fantastyczne. Vico przedstawia oryginalną koncepcję ich powstania. Zdaje się, że pojawiły się tylko dlatego, iż miały charakter przystosowawczy do środowiska, w którym żył gatunek ludzki. Potem jednak, w miare jak rozwijat sie umyst ludzki, wynaleziono stowa oznaczajacce formy abstrakcyjne lub rodzaje (generi) obejmujacce różne gatunki (specie) albo tączace cześsi w catość. Wówczas

44 D.P. Verene, Lóriginalitá filosofica di Vico, [w:] Vico oggi, ed. A. Battistini, Roma 1979, s. 97, Filosofia eproblemi d'oggi, 73. Nuovi studi vichiani, 4 .

45 Vico e il pensiero contemporaneo..., s. 199.

46 M. Danesi, Vico, Metaphor..., s. 49.

47 G. Bedani, Vico Revisited..., s. 54.

48 Vico e il pensiero contemporaneo..., s. 224-241. 
wyrażenia pierwszych narodów staty się metaforycznymi zwrotami retorycznymi $i^{49}$. Jedyne „abstrakcje” ludzi pierwotnych to łączenie rzeczy na zasadzie podobieństw, jak robią to dzieci. Przeczy to różnym wariantom koncepcji natywistycznych, zwykłych w bardziej wysublimowany sposób dochodzić źródeł tych arcyludzkich zdolności dążenia do ogólności, ujmowania w kategorie itd. Kolejność idei ludzkich polega na obserwowaniu rzeczy podobnych, najpierw po to, aby sie wypowiedzieć, potem, by dowiesśs ${ }^{0}$. Umystom ograniczonym wystarcza jednak tylko jeden przypadek podobieństwa, by daty się przekonać. Stato się to nie dzięki rozumowaniu, do którego nie byli jeszcze zdolni, lecz za sprawa zmystów omylnych $w$ trésci, ale prawdziwych $w$ formie, taka bowiem logika odpowiadata ich naturze $e^{51}$.

Uniwersalia miały pierwotnie jedno, najważniejsze zastosowanie. Dzięki nim możliwe było powstanie pierwszej moralności, przedstawienie wspólnocie ideałów etycznych w postaciach bohaterów, pożądanych struktur społecznych itd. Fantastyczny powszechnik był dokonaniem „cywilizującym”: Arystoteles stwierdza celnie w jednym z miejsc swojej „Etyki”, że ludzie ograniczeni uogólniają każdy poszczególny przypadek. A to $z$ tej przyczyny, że umyst ludzki, z natury nie znający ograniczeń, byt wówczas skrępowany wybujatościa zmystów i mógt ujawnić swoją niemalże boskq naturęjedynie wyolbrzymiając za pomoca wyobrażeń rzeczy poszczególne $e^{52}$. Rodzaje fantastyczne czy uniwersalia fantastyczne pomagają Vicowi zrekonstruować początki historii politycznej, ponieważ łączą myśl ludzką z ówczesnymi realiami życia, zatem przekazują żywe świadectwo tamtych czasów.

Powiemy jeszcze krótko, po czwarte, o ważnym z epistemologicznego punktu widzenia dla Vica słowniku powszechnym ludzkości i Wiecznej Historii Idealnej.

Pracując nad konceptem Wiecznej Historii Idealnej, Vico zastanawiał się też nad ideą słownika rozumowego, który by określił znaczenie słów we wszystkich językach artykułowanych. Rzecz sprowadza się do jednakowych wistocie swej idei, którym jednak różne narody, różnie je ujmując, nadaty odmienne nazwy. Stownikiem tym postugujemy się stale $w$ rozważaniach wchodzacych $w$ sktad naszej Nauki $i^{53}$. Miał on służyć do translacji pojęć, a przede wszystkim nazw i znaczenia instytucji oraz wytworów, tak żeby można je było porównywać. Byłoby to podobne sprowadzaniu do tej samej jednostki miar po to, żeby później robić na danych operację. Operacją zaś w tym przypadku miałoby być wydobycie i nakreślenie Wiecznej Historii Idealnej (w skrócie: praw historii). Wieczna Historia Idealna musiałaby znaleźć wyraz w zbieżnościach pomiędzy narodami ujętych w słowniku rozumowym wszystkich języków ${ }^{54}$.

Jego ustanowienie było dla Nauki nowej nie tylko celem do osiągnięcia, ale wręcz założeniem, które Vico musiał brać pod uwagę a priori, zanim przystąpił do pisania. Jak

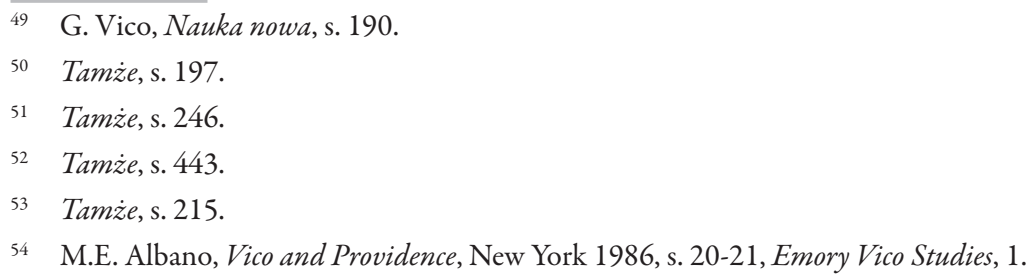


się okazało, Vico poprzestał na przypuszczeniu. Wpierw powziął pomysł etymologii wspólnej wszystkim językom, potrzebnej naukom o języku po to, żeby ustalić właściwości naturalnego prawa narodów. Było to szukanie u początków języków łacińskich, prowadzone na podobieństwo Platona, który poszedł do Kratyla, żeby badać początki języka greckiego. Vico nie zdołał jednak tego zrobić, gdyż jak twierdzi w De antiquissima, skoncentrował się zbytnio na czymś, co nazywano filologia sekretną renesansu, a co zostało już przedstawione: poszedł w stronę inwencyjności i politykotwórczych walorów języka. Z tego powodu, że język u początku został „zabarwiony” inwencyjnością, nabył przekonania, że sapientia veterum, czyli mądrość poetów, która objawiła się u tychże poszukiwanych początków języków, zakryła welonem prawdę filozoficzno-konceptualną etymologii łacińskiej, uniemożliwiając zatem odnalezienie jej w czystej postaci. Znalazł tym samym usprawiedliwienie dla własnego niesprostania założeniom ${ }^{55}$.

Rozważania o języku poetyckim jako „budulcu” starożytnego świata społecznego oraz historyczności człowieka wypada zakończyć umiejscowieniem ich na tle całości teorii wyłożonej w Nauce nowej. I tak, w Wiecznej Historii Idealnej, pojętej i jako narzędzie segregowania faktów, i jako stała struktura, na którą te fakty się składają, zostają zunifikowane dane z różnorodnych kultur ludzkich. Żeby pomyśleć świat jako taką totalność, trzeba zaimprowizować kreację stabilnego punku odniesienia, pojęcia-zasady czy też pojęcia-konceptu, które zjednoczy w sobie kompletne znaczenie historii i kultury, czym jest dla Vica Wieczna Historia Idealna. Jej odkrycie zawdzięcza on prawidłom wygenerowanym w czasie długoletnich badań i rozumiejącej obserwacji świata starożytności poetyckiej. Tak, jak przeciwstawiał się powszechnym sądom o tym, że mity falsyfikują albo zniekształcają rzeczywistość, na nieco wyższym poziomie ogólności przyznał, że w ten sam sposób Wieczna Historia Idealna jest także prawdziwą narracją. Ingegno w Nauce nowej zbiera - w końcowym efekcie, to jest w Wiecznej Historii Idealnej - to, co uniwersalne. Vico sam zastosował metodę ingegno, którą opisywał, żeby stworzyć topos fundamentalny dla czasu. Chciał zamknąć historię w takim modelu, jaki geometria kładzie na świat przestrzenny. Jeśliby stwierdzić, że to, co zrobil, to nauka, należy dodać, że z pewnością to nauka nowa. Nie daje bowiem wiedzy stosowalnej na przyszłość, która pozwoliłaby wyznaczyć, co i kiedy się stanie. Jednak nie jest to też tylko zdolność zapamiętywania wydarzeń osadzonych w uporządkowanej formie, ale sposób wyciągania prawdy czy prawd - Vico powiedziałby może mądrości - poprzez uporządkowaną pamięć historyczną. Pamięć z kolei jest pewnym pietyzmem wobec historii, a ta - postawą konkretnego człowieka czy środowiska. I tak koło nawraca od naukowych poszukiwań do osobistych i środowiskowych przyczyn wygenerowania genialnego dzieła, jakim jest Nauka nowa ${ }^{56}$.

W Pryncypiach Nauki nowej Vico podał pierwszy raz rewolucyjną z punktu widzenia filozofii języka, gnoseologii i historii duchowości tezę o konieczności poetyckiej fundacji rzeczywistości ziemskiej. Nie chciała się na to zgodzić „próżność” uczonych, o której Vico także mówił sporo. Wykazaliśmy, iż wskutek stabości rozumowania

\footnotetext{
55 Vico e il pensiero contemporaneo..., s. 198-199.

56 Tamże, s. 100-113.
} 
ludzkiego narodzita się poezja tak wzniosta, że ani późniejsze systemy filozoficzne, ani nawet sztuki poetyckie czy krytyczne nie zdotaty jej dorównać, a cóż dopiero przewyższyc ${ }^{57}$. Dlatego późniejsi, ogarnięci próżnością uczeni, próbując przybliżyć czasom im współczesnych mity starożytne, zdołali jedynie je wypaczyć. Cały fantastyczny świat starożytny polegał na „wiarygodnej niemożliwości” („l'impossibile credibile”) ${ }^{58}$, której nie można tłumaczyć inaczej.

Uderza niedostrzeganie przez Vica dysonansu pomiędzy prymitywnością, pierwotnością człowieka a poetyckością jego najwcześniejszej historii, w której obecni byli także „poeci-teologowie”. Według jego teorii ewolucji języka najniższemu poziomowi rozwoju człowieka odpowiada język poetycki, w potocznym, współczesnym mniemaniu uważany za najbardziej wysublimowany, plasujący się na szczytach ludzkich możliwości. Trudno się dziwić zatem „próżności” uczonych, którzy chcieli w owej poezji widzieć więcej, niżby pozwalał Vico. Mądrość poetycka dotarła do czasów Vica wprawdzie otoczona szacunkiem, ale ten wynikał - jego zdaniem - z niezrozumienia. Przyczyniła się do tego owa próżność (boria). Ona to sprawita, że Manethon, arcykaptan egipski, podnióst cata bajeczna historię egipska do rzędu wzniostej teologii naturalnej [...] oraz że filozofowie greccy dali swej mitologicznej historii interpretacje filozoficzna ${ }^{59}$. Chodziło o wykorzystanie dokonań starożytnych poprzez dostarczenie ich wypaczonej interpretacji i za cenę zmanipulowania prawdy zaprzęgnięcia ich w służbę państwu, społeczeństwu i nauce. Późniejsze interpretacje miały także wzgląd na umocnienie kultu religijnego i wiary w opatrzność. Treść mitów stanowiła zachętę do podjęcia najważniejszych problemów filozoficznych; tutaj używano bajek jedynie jako dogodnych środków wyrazu, rozległych i pojemnych figur retorycznych, w których zawierano nową „mądrość” i nieznane starożytności poglądy, uzyskując dla nich autorytet, co też było „próżnością” nauki.

Tymczasem owo „uwznioślanie” było przecież całkowicie obce pierwotnemu charakterowi mądrości poetyckiej. Była to mądrość pospolita, która najpierw poeci odczuwali, filozofowie z kolei pojęli jako madrość refleksyjna (sapienza riposta). Pierwszych zatem można nazwać zmystami, drugich zaś intelektem rodzaju ludzkiego ${ }^{60}$. Otóż gramatycy dopatrywali się przejawów sztuki w tym, co byto skutkiem ubóstwa środków wyrazu. Był to bowiem język ludzi niewykształconych, a potrzeba wysłowienia tego, co odczuwali, to tylko jeden krok dalej od zwierzęcego krzyku. Tropy były koniecznymi środkami ekspresji, nie były świadomym zabiegiem przekazujących historie. $Z$ tej racji twierdziliśmy w Aksjomatach, „dzieci szczególnie celuja w naśladowaniu”, „poezja jest tylko naśladowaniem" $i$ "umiejętności sa tylko naśladowaniem natury; a więc w pewnym sensie realna. poezja." Tak oto najpierw ludy pierwotne, które byty dziećmi rodzaju ludzkiego, stworzyty świat sztuki, następnie zaśfilozofowie, którzy sa starcami narodów, gdyż pojawili się znacznie później, stworzyli świat nauki. W ten sposób dokonato się catkowicie dzieto cywilizacji ${ }^{61}$.

57 G. Vico, Nauka nowa, s. 432.

58 Vico eilpensiero contemporaneo..., s. 173.

59 G. Vico, Nauka nowa, s. 156.

60 Tamże.

61 Tamże, s. 242. 
Powróćmy teraz do dalszego opisywania, co działo się u początków tak ufundowanej pierwszej wspólnoty politycznej. Powiemy o konkretnych krokach w stronę budowania państwa i o jego specyficznej moralności, to jest o bohaterach. Jeśli za cechy bohaterstwa weźmie się chociażby takie, jak świętość, walory intelektualne, szlachetność duszy, pożyteczność i piękno, nie wiadomo, czy w polityce poetyckiej Vica zachowałby się choć jeden z bohaterów. Piękno społeczne rzeczywiście było tam sławione, ale był to stan osiągnięty na skutek współpracy tychże bohaterów z opatrznością, nie pochodził od nich samych. Kolejny raz zadziałała tutaj próżność uczonych, gdyż przypisano bohaterom wynalezienie instytucji podobnych do tych istniejących w późniejszych, bardziej oświeconych czasach. Stało się tak dlatego, że źle i bez patrzenia na kontekst poetycki rozpatrywano znalezione w mitach i historii starożytnej pojęcia ludu, wolności i króla. Bohaterowie Vica nie mieli nic wspólnego ani z ideałem chrześcijańskim, ani z ideałem klasycznym, filozoficznym, np. Arystotelesa. Jeśliby próbować „podciągnąć" ich pod bohaterskość tzw. wojenną, wystarczy popatrzeć na starcie bohaterów pod Troją, by odmówić im pragnienia chwały wojennej, nieśmiertelności czy sprawiedliwości i utożsamić z narcyzmem i kaprysem. Zatem Vico nie znalazł u początków świata społecznego kogoś, kto łączyłby mądrość z siłą. Opatrzność działała raczej przez wady. Używając słów Machiavellego, można by powiedzieć, że nie było wtenczas kogoś, kto połączyłby gwałtowność Romulusa z respektem i refleksyjnością Numy, nie było szlachetnego polityka-centaura Charona. Boskość tamtych odległych czasów była okropna, straszna, despotyczna i olbrzymia po to, aby zmusić gigantów do zduszenia swoich pasji; w świecie tym panował wręcz terror religijny. Bohaterowie byli skrojeni na miarę takiego świata ${ }^{62}$.

Bohaterowie, wysłuchawszy bogów, przeszli to osiadłego trybu życia (przez to Jowisz zyskuje przydomek Stator) i jako poeci-teologowie rozpoczęli tworzenie wspólnoty politycznej. Zaczęli zajmować się rolnictwem i skończyli z dzikim życiem. Zrodziły się wtedy bóstwa natury oraz te odpowiedzialne za powodzenie pracy rolników. Ludzie weszli w posiadanie sensu czasu i przestrzeni. Ci najbardziej zwierzęcy, najbardziej gigantyczni zostali „porażeni” przez boski piorun i rozpoczęli projekt cywilizacyjny. Słabi pozostali zamknięci w dzikim świecie i trwali w stanie przedprawnym (ex lege) pod patronatem mocniejszych. Kiedy chcieli poprzez azyle dostać się do miast bohaterskich, od początku musieli się zgodzić na niższą pozycję famuli, a przecież różnili się jedynie stopniem i czasem rozpoczęcia hamowania swoich żądz. Hierarchia ta była jednak bardzo surowo przestrzegana. Cały proces „osiadania” rzeźbił cnoty oraz umiejętności społeczne ludzi. Bohaterowie nie byli jednak świadomi „wykorzystania” ich przez opatrzność. Pierwsi świadomość zyskali plebejusze, gdyż porównywali się z arystokracją, by stwierdzić, że są tej samej, nie gorszej natury i w wojnach cywilnych kształcili się do zrównania w władzy lub do jej całkowitego przejęcia ${ }^{63}$.

Moralność poetycka wychodziła z pobożności i prowadziła do niej z powrotem. Po czasach stadnego i zwierzęcego życia powstały małżeństwa, ale przysługiwały tylko

\footnotetext{
62 A. Battistini, Vico e gli eroi fondatori delle nazioni, Roma 2003, s. 229-233.

63

Tamże, s. 239-246.
} 
bohaterom, dlatego Amor bohaterski miał opaskę na oczach i był uskrzydlony, co oznaczało wstydliwość i świętość. Innymi obrzędami wyznaczającymi kres życia po wyjściu z natury było świętowanie narodzin i oddawanie czci zmarłym poprzez uroczyste pochówki. Moralność poetycka była bardzo surowa. Polegała na złagodzeniu zwierzęcości tam, gdzie wymagał tego obłędny strach przed Jowiszem, poza tym zaś, jeżeli chodzi o wspólne życie społeczne, gospodarowanie, podbój, utrzymanie - panowały nadal barbarzyńskie obyczaje. $Z$ tego wszystkiego należy wyciagnać wniosek, iż tylko pobożność sktaniata uczonych do czczej wiary w niewinność wieku ztotego pierwotnych narodów pogańskich. W rzeczywistości byt to wiek zabobonnego fanatyzmu i tylko lęk przed którymś z fanatycznych bóstw utrzymywat pierwotnych, barbarzyńskich, dumnych i dzikich ludzi świata pogańskiego w jakichś karbach ${ }^{64}$.

Bohaterowie zachowywali taką pobożność. Mówią o tym ich bóstwa. Na przykład Diana bohaterska była symbolem czystości, którą naruszył, przyglądając się jej kąpiącej, Akteon, po czym zamienił się w jelenia, symbol największej płochliwości, jako że przeraził się tym, co uczynił, na końcu zaś rozszarpały go psy Diany, czyli jego własne wyrzuty sumienia. Z kolei opowieść o Apollo i Dafne w oryginale ma całkiem inną wymowę, aniżeli jej się powszechnie nadaje, mianowicie że bezwstydny Apollo miał gonić Dafne, wyratowaną przez bogów, do których się zwróciła, poprzez zamienienie w drzewo laurowe. Apollo, czyli jasny, był u bohaterów bogiem spraw cywilnych, goni zaś Dafne dlatego, że ta dziewczyna z ludu miała zamiar znów zabłądzić w dzikie lasy, to jest powrócić do stanu zwierzęcego. Zostaje przemieniona w drzewo laurowe, symbol płodności pobłogosławionej uroczystymi obrzędami ślubnymi. Vico dopowiada, że długo w czasach poetyckich nazywano potomków od pędów, gałęzi - pomocna jest mu tutaj etymologia ${ }^{65}$.

W taki sposób w opowieściach umieszczano pewne wymogi, które człowiek cywilizujący się uznawat. Węże, które zdusił, w kolebce jeszcze będąc, Herkules czy te, które zrodziły się w Tebach z zębów zasianych w ziemi przez Kadmusa, miały być symbolem własności. Miał je także w herbie obrotny i zapobiegliwy Merkury, opiekun handlarzy i wszelkiej przynoszącej dochód działalności ${ }^{66}$. Nazwa urbs oznaczająca miasto znaczyła dosłownie „krzywy” od wytyczania granic miast pługiem i strasznych obrzędów, które zdobywaniu i ugruntowaniu nowej własności towarzyszyły, zaś orbis pochodzi od ogrodzenia $^{67}$. Kolejne przekłamania wynikające z nazbyt udziwnionej i niezwykłej interpretacji prostego języka poetyckiego starożytności Vico prostuje, podając między innymi, że wiek złoty nie pochodził od bogactwa, ale od lanów zboża, które ludzie, osiadłszy, uprawiali; rodzina, czyli familia, powstała oprócz dzieci i rodziców z famuli, czyli tych mniej dorodnych olbrzymów, którzy za mało zlękli się Jowisza, by rozpocząć życie cywilizowane, błąkali się po lasach, aż horror życia zwierzęcego okazał się nieznośny i najęli się na służbę do bohaterów - będą to później walczący o wyemancypowanie plebejusze.

64 G. Vico, Nauka nowa, s. 258.

65 Tamize, s. 266-271.

66 Tamże, s. 274.

67 Tamże, s. 281-282. 
Clienti pochodzi od nazwy oręża, gdyż użyczali oni bohaterom pomocy w wojnie, liberi było nazwą synów bohaterów, socii, tych, którzy współpracowali przy polach i innych gospodarskich sprawach. W czasie po osiedleniu się za oświeceniem Jowisza powstały też pierwsze lenna i azyle dla uciekających od gwałtu pod tarczę i strzechę bohaterów. Język poetycki wszystko to komunikował, nazywał, a przyczynę działań wyjaśniał.

Wypada tutaj powiedzieć jeszcze o jednym bóstwie - Wenus, gdyż Vico nie tylko wyjaśnia prawdziwe znaczenie mitu o niej, ale też abstrahuje ten pomysł jako jeden z najpiękniejszych przejawów cywilizowania się człowieka i w toku rozwijania Nauki nowej przypomina. Drugim bóstwem, zrodzonym w tych zamierzchtych czasach, byta Wenus, która stata się symbolem urody spotecznej (bellezza civile). Dlatego honestas oznacza $i$ „szlachectwo", $i$ "piękno", $i$ „cnotę". W takiej wtaśnie kolejności zapewne narodzity się trzy pojecia. Pierwsza uroda byta bowiem uroda spoteczna, wtaściwa bohaterom. Druga uroda naturalna, dostrzegalna dla zmystów, jakimi dysponuja ludzie o umystach roztropnych i pojętnych, zdolnych rozróżniać części oraz oceniać ich harmonię w catoksztatcie ciata, gdyż na tym wtaśnie polega istota piękna. [...] Trzecia wreszcie uroda byta uroda cnoty, zwana honestas, która rozumieli tylko filozofowie ${ }^{68}$. Piękno społeczne dostrzeżone zostało pierwszy raz przez bohaterów, którzy jakoby docenili już swój wysiłek wyjścia ze stanu dzikości do stanu cywilizowanego. Uznali także, że dobry jest kierunek, w którym prowadzi ich Jowisz - nieuświadamiana przez nich opatrzność. Idea piękna spotecznego musiata się narodzić w umystach poetów-teologów wówczas, kiedy ujrzeli, że chroniący się na ich ziemię barbarzyńcy maja wyglą ludzki, lecz obyczaje dzikich zwierzą ${ }^{69}$.

$\mathrm{Z}$ takich to mniej więcej względów musiało się rozpocząć odróżnianie patrycjuszy, możnych czy też dawnych bohaterów, od plebejuszy, których ci pierwsi wyprzedzili na drodze cywilizowania się, zaś pokrewieństwa i równości z nimi już nie chcieli na powrót uznać. Plebejusze mieli dostęp tylko do wróżb prywatnych, mniejszych. Skoro chcieli uprawiać ziemię, mogli to czynić tylko biorąc ją w dzierżawę i płacąc czynsz. Bohaterowie przestrzegali zasady pokrewieństwa, przedział między możnym i famulami był nieodwołalny. Prowadzono mało wojen, bo nie chciano ćwiczyć plebejuszy w rzemiośle wojennym, żeby kiedyś się nie oswobodzili. Mądrość poetycką starano się zachować tylko do wiadomości bohaterów. Cóż z tego, skoro odtajniała się ona poprzez zbiorowe, publiczne uroczystości, a także zwykłe obserwacje panów prowadzone przez famuli. Utrzymywano jednak władzę; dewiza republik arystokratycznych, które nastały po władzy protokrólewskiej ojców w rodzinach, brzmiała następująco: w związku najlepszych spoczywa mądrość miast ${ }^{70}$. Stopniowo poprzez ustawy, między innymi pierwszą ustawę rolną, a także różnego rodzaju lenna plebejusze zaczęli znaczyć coraz więcej. W sposób pośredni wpływało to na zmianę języka, moralności, wypaczenie mądrości poetyckiej i kultu.

U schyłku starożytności greckiej ten podział społeczny nabrał nowej dynamiki. $\mathrm{Z}$ jednej strony byli to mędrcy i pospólstwo (profano - niewtajemniczone), z drugiej

Tamże, s. 294.

69 Tamże.

70 Tamże, s. 310. 
civis i hostis, obywatele i wrogowie. Plebejusze byli zawsze grupą, która chciała zmienić ustrój państwa, patrycjusze chcieli go zachować ${ }^{71}$. Symbolem ich usilności są kochankowie, którzy u boku Penelopy chcą zastąpić Odysa, a których ta musi zbywać pruciem koszuli - obietnicami bez pokrycia, dotyczącymi chociażby przyznania plebejuszom prawa do uroczystych małżeństw ${ }^{72}$. Końcem epoki starożytności było przyznanie wreszcie praw plebejuszom ${ }^{73}$, które zamknęło epokę poetycką, gdyż nastał język porozumienia wewnątrzpaństwowego, a język „rozumienia” opatrzności stracił pierwszoplanowe znaczenie.

Innym zadzierzgnięciem nici historii z nicości, nieco mniej poetyckim, a bardziej dosłownym, jest wytłumaczenie, że ludzie pierwotni pragnęli pomocy nadnaturalnej, tzn. przymnożenia swoich sił, przez co uznali opatrzność, która pozwoliła im popaść w błąd sądzenia o Jowiszu-niebie, że jest prawdziwym bogiem. Początki te dostarczają jeszcze jednego pojęcia, na którym oparło się wiele starożytnych instytucji, pierwotnie odnoszonego tylko do Boga-autorytetu. Autorytet byt na początku autorytetem boskim i jego moca bóstwo podporzadkowato sobie wspomnianych już nielicznych olbrzymów, obalając ich na ziemię i ukrywając w gtębi jaskiń u podnóża gór ${ }^{74}$. Autorytet opatrzności „przeważy”” nad wolą i opinią poszczególnych ludzi; działał na społeczność, a nie na jednostki. Jedynym zastrzeżeniem co do tego jest jego oddziaływanie proporcjonalnie mocniejsze na „dorodniejszych” przedstawicieli - najbardziej porażeni przez grom zostali ci, którzy wdrapali się najwyżej na góry, czyli najsilniejsi i najdzielniejsi. Plan opatrzności ugruntowywał i wykorzystywał naturalną strukturę grup. $\mathrm{Z}$ tego samego rdzennego doświadczenia cywilizacji powstała nauka: $W$ nauce augurów Rzymianie nazywali contemplari obserwowanie tych części nieba, na których pojawiaty się znaki wróżebne. Owe regiony nieba, zakreślane przez augurów laska, zwaty się templa coeli; Grecy widzieli w nich teoremata lub matemata, „Boskie lub wznioste rzeczy godne kontemplowania", które następnie znalazty swe zastosowanie w abstrakcjach metafizyki i matematyki $7^{75}$. $\mathrm{Z}$ niego wreszcie powstała polityka i prawo: Nasze rozważania o prawie naturalnym rozpoczynamy od jego pierwotnej formy boskiej; byto ono wówczas wróżbiarstwem, czyli naukq o auspicjach Jowisza; stanowito zatem sferęrzeczy boskich, wedle której narody pogańskie regulowaty sferę swoich ludzkich spraw ${ }^{76}$.

Chociaż w zakres mądrości poetyckiej prezentowanej w Nauce nowej Giambattisty Vica wchodzi wiele jeszcze inspirujących dociekań, jak chociażby podważenie istnienia Homera, przekształcenie języka w epoce rzymskiej i jego degradacja wraz z zatoczeniem koła przez ricorso historii i nawrotem barbarii, to poprzestaniemy na tym dość wyczerpującym nakreśleniu jej charakteru i pokusimy się o parę wniosków. Przede wszystkim jako życzliwi czytelnicy Jana Sebastiana Vica z żalem musimy się odnieść do tego,

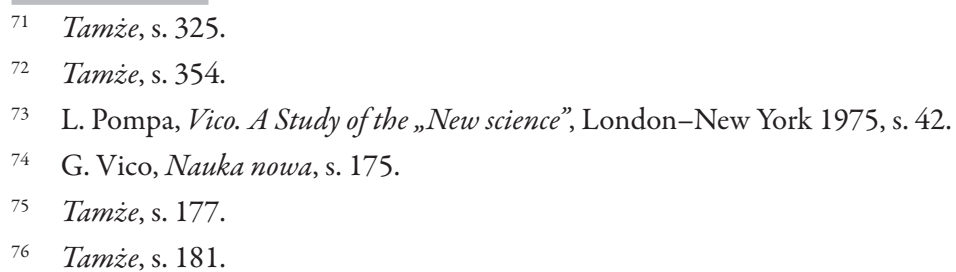


że tak kompletna, jak zostało to tutaj przedstawione, spójna, zaopatrzona we własne narzędzia poznawcze wizja początków państwowości nie znajduje się na liście obowiązkowych lektur z klasycznej filozofii polityki. Rzecz to smutna, bo przy okazji wskazuje, że dorobek renesansu, z wyjątkiem Machiavellego, wciągniętego na listę protoplastów Realpolitik, zostaje pominięty niezrozumiałym milczeniem na polskich wykładach z filozofii polityki. Przedstawiliśmy tutaj Vico na tle poważnej szkoły renesansowej, osadziliśmy go zresztą wyraźnie w kontekście życia intelektualnego Włoch, które niechętnie przyjmowało nowinki kartezjańskie, gdyż samo było zajęte własnymi dociekaniami. Jak wskazują jego badania, hipotezy Hobbesa czy Locke’a dotyczące umowy społecznej są o tyle nietrafione, że język, jakim dysponował człowiek pierwotny, nie był w stanie sprostać prawniczej precyzji, a wspólnota ludzka musiała się rozwijać w sposób bardziej organicystyczny.

W Polsce znany przede wszystkim z pracy Filozofia dziejów. Rozwój problemów $i$ stanowisk Zbigniewa Kuderowicza Vico ma do zaoferowania znacznie więcej aniżeli teorię nawrotów historii. W rzeczy samej we Włoszech sięgają po niego kolejne pokolenia badaczy z różnych dziedzin - od lingwistyki, poprzez antropologię, aż do nauk politycznych i filozofii właśnie. O ile sam sposób obrony przez „unaukowieniem” na modłę nowożytną nauk społecznych - jak to się zresztą po części stało - jest motywowany u Vico niejako odruchem profesora „starej daty”, który retorykę i wszystko w ogóle, co najlepsze, widzi w antycznych wzorcach, o tyle zwrócenie uwagi na język jako tworzący rzeczywistość i jako narzędzie jej zmiany jest poglądem, którego nie powstydziłby się XX-wieczny filozof. Zwraca uwagę przede wszystkim epistemologia Vica, która wymagałaby osobnego potraktowania, gdyż zaprezentowane tutaj jej elementy są tylko wyjątkami z imponujących badań autora Nauki nowej. Przede wszystkim wydaje się, że uważna lektura Vica stwarza nowe przestrzenie wyobraźni dla filozofa politycznego oraz podważa utarte i może nazbyt spłycone drogi rozumowania. Wszak sam Vico sądził, że racjonalność ma tendencję do odrywania się od rzeczywistości lub przeintelektualizowania, które są zawsze syndromem wsteczności, nie rozwoju. Lektura Vica pozwala w tym sensie odświeżyć umysł, a także wyzbyć się chęci trzymania się bezpieczeństwa sztampowych interpretacji, gdyż głosy odrębne w dyskusji wnoszą dużo nowości, równie inspirująca jest też charakteryzująca je intelektualna odwaga.

\section{BIBLIOGRAFIA}

Albano M.E., Vico and Providence, New York 1986, Emory Vico Studies, 1.

Battistini A., Vico e gli eroi fondatori delle nazioni, Roma 2003.

Battistini A., Vico lettore agonistico, „Studi di Estetica” 1991, R. 19, ser. 3, nr 3/4.

Bedani G., Vico Revisited. Ortodoxy, Naturalism and Science in the Scienza Nuova, Oxford 1989.

Danesi M., Vico, Metaphor, and the Origin of Language, Bloomington 1993, Advances in Semiotics.

Grassi E., Vico and Humanism. Essays on Vico, Heidegger and Rhetoric, New York 1990, Emory Vico Studies, 3. 
Marassi M., Leonardo Bruni e la teoria della traduzione, „Studi Umanistici Piceni” 2009, Vol. 29, [online] http://tuttoscorre.org/wp-content/uploads/2014/05/Leonardo_Bruni_e_la_ teoria_della_traduzione.pdf.

Mooney M., Vico e la tradizione della retorica, Bologna 1991, Saggi, 394.

Pompa L., Vico. A Study of the „New science”, London-New York 1975.

Vico G., Il metodo degli studi del tempo nostro, przeł. i oprac. A. Corsano, Firenze 1948.

Vico G., L'Antichissima sapienza degli italici, da estrarsi dalle origini della lingua latina, [w:] tenże, La scienza nuova e opere scelte, przeł. N. Abbagnano, Torino 1952.

Vico G., La difesa dell'umanesimo. De nostri temporis studiorum ratione, przeł. i oprac. M. Goretti, Firenze 1967.

Vico G., Nauka nowa, przeł. J. Jakubowicz, oprac. S. Krzemień-Ojak, Warszawa 1966, Biblioteka Klasyków Filozofii.

Vico G., The Autobiography of Giambattista Vico, przet. M.H. Fisch, T.G. Bergin, Ithaca 1944.

Vico e il pensiero contemporaneo. Atti del Convegno Internazionale "Vico e il pensiero contemporaneo", Lecce, Novembre 9-11, 1989, ed. A. Verri, Lecce 1991.

Vico oggi, ed. A. Battistini, Roma 1979, Filosofia e problemi d’oggi, 73. Nuovi studi vichiani, 4.

Mgr Aleksandra ZAJĄC (ur. 1985) - absolwentka studiów magisterskich z zakresu stosunków międzynarodowych oraz filozofii na Uniwersytecie Jagiellońskim w Krakowie, obecnie doktorantka macierzystego uniwersytetu, w czasie studiów stypendystka Programu Socrates-Erasmus na Università degli Studi di Bologna, gdzie pisała pracę magisterską o Giambattiście Vico, nauczycielka języka włoskiego. 